\title{
Formidling af den lokale kulturarv på nettet
}

\section{Af Ruth Hedegaard og Asbjørn Hellum}

Den lokale kulturarv befinder sig i hovedsagen på de tre lokale kulturinstitutioner - museer, arkiver og biblioteker. De tre institutionstyper har haft hvert sit udviklingsforløb og har derfor udviklet sine specielle formidlingsformer også bestemt af de forskellige samlinger.

De tre institutioner bidrager med deres forskellige samlinger, viden samt deres forskellige faglighed til en meget værdifuld og vigtig del af den danske kulturarv. Biblioteket som det lokale informationscenter, museet med de fysiske samlinger og beskrivelserne heraf og arkivet med den autentiske dokumentation til historien.

Som det er i dag, er det for brugeren af de forskellige kulturtilbud en stor fordel at være fortrolig med de specielle formidlings- og tilgængelighedsformer i den enkelte institution. Institutionernes forskellige registreringsmetoder g $\varnothing \mathrm{r}$ det vanskeligt for brugeren at finde den relevante information. Mens biblioteker og museer er velkendte og forankrede institutioner i det danske samfund med et nogenlunde ensartet præg, med personale, faste budgetter etc., er det her på sin plads at redegøre lidt grundigere for de lokalhistoriske arkiver og deres betydning og organisation.

\section{Lokalhistoriske arkiver i Danmark}

Det første egentlige lokalarkiv daterer sig til 11. juni 1937. Efter at en stor samling af arkivalier og billeder var blevet brændt, tog Hans Brandt initiativ til at samle en række lokalhistorisk interesserede borgere for at forhindre, at noget lignende skulle ske igen. Dette initiativ førte til oprettelsen af Fåborg lokalhistoriske Arkiv.

Oprettelsen af flere lokalarkiver fulgte i moderat tempo. I 1949 stiftede fem lokalarkiver landsorganisationen Sammenslutningen af Lokalhistoriske Arkiver (SLA). Antallet af lokalarkiver var i 1960 steget til ca. 30 lokalarkiver.

I 1960erne skete samfundsforandringerne med en sådan hastighed, at det var tydeligt for enhver, at man år efter år mistede de gammelkendte træk ved lokalsamfundene. Skulle man bevare vidnesbyrd herom, måtte der gøres en bevidst og systematisk indsats.

Omkring 1970 havde landsorganisationen derfor allerede 75 medlemsarkiver. Udviklingen accelererede yderligere i 1970erne og 1980erne med rationalisering og koncentration som hovedtema. Det gav yderligere vind i sejlene til den lokale arkivbevægelse, som resulterede i et sandt boom i oprettelse af lokalarkiver. Fra 1970 til 1980 steg 
SLAs medlemstal fra 75 til 279. Den udvikling er fortsat, så der i dag findes ikke færre end 450 lokalarkiver. Der er således ikke en krog af Danmark, der ikke har sit eget lokale arkiv.

Størrelsen af arkiverne varierer utrolig meget. De mindste arkiver drives udelukkende ved frivillig og ulønnet arbejdskraft, måske i et lille lokale på den stedlige skole og med et årsbudget på under $5.000 \mathrm{kr}$. De største lokalarkiver har en medarbejderstab på op mod femten faste medarbejdere og et fast budget. I mange tilfælde har de ansvaret for de kommunale arkivalier.

Der foregår i dag en markant udvikling i retning af en professionalisering af det lokalhistoriske arkivarbejde på linie med den professionalisering, som biblioteker og museer har gennemgået.

I lokalarkiverne arbejdes der med at indsamle, bevare og formidle de historiske kilder, som stammer fra lokalsamfundene. De er af stor betydning for indsamlingen og bevarelsen af det lokale historiske materiale, idet private personer, foreninger, organisationer, firmaer, handelsvirksomheder o.s.v. ikke er lovmæssigt bundne til at aflevere deres materiale til en offentlig samling eller overhovedet bevare det.

Det statslige arkivvæsen samler ikke systematisk private arkiver i Danmark, så der er en stor opgave for de lokale arkiver, som i $\varnothing v$ vrigt ikke blot indsamler arkivalier og fotos, men også kort, audiovisuelt materiale, aviser, småtryk og bøger.

Efter indsamlingen ordnes og registreres materialet og stilles til rådighed for de interesserede brugere, bl.a. ved hjælp af edb-systemet ARKIBAS, som i dag findes i 275 st $\varnothing$ rre og mindre lokalarkiver.

\section{ARKIBAS (Lokalarkivernes fælles edb-program)}

Selvom arkiverne udgiver bøger, laver udstillinger, holder foredrag mv., så består hovedformidlingen i at stille deres samlinger til rådighed for den interesserede bruger, der aflægger arkivet et besøg.

Siden 1988 har lokalarkiverne anvendt den nye edb-teknologi i registrerings- og formidlingssam- menhæng. Da kunne man tage arkivernes specialudviklede registreringsprogram, ARKIBAS, i brug. Programmet håndterer arkivernes materiale fra den første kontakt i forbindelse med aflevering, til det står pakket og registreret på hylderne og med et søgesystem tilknyttet. I $\varnothing v$ vigt blev det for mange år siden besluttet at tage udgangspunkt i bibliotekernes DK5 som søgesystem.

Hvad fotos og andet visuelt materiale som kort m.v. angår, så er det muligt at se en gengivelse heraf sammen med registreringen.

Programmet er i stand til at håndtere det brede spektrum af materialer, som udg ør arkivernes samlinger.

\section{ABM-samarbejde}

De tre institutioner er forskellige, men supplerer hinanden, og det afhænger af brugerens behov, hvem det er mest formålstjenligt at besøge. Er det en skoleklasse, der skal have et overblik over et emne, findes det nemmest og hurtigst på biblioteket, er det en forsker, der unders $\emptyset$ ger Indre Missions udbredelse i Vendsyssel, vil hun have stor gavn af arkivalierne på lokalarkivet. Er det en bruger, der kan huske en rok fra sit barndomshjem og gerne vil vide mere om den, finder hun sikkert bedst oplysningerne på museet.

Problemet er blot, at mange ikke i forvejen ved, hvor de skal gå hen afhængigt af deres behov.

For brugerne er det ikke interessant, om de kan finde de oplysninger, de søger, i en bog eller et småtryk fra biblioteket, ved en beskrivelse af en museumsgenstand eller i en foreningsprotokol, blot de finder de $\varnothing$ nskede oplysninger.

Derfor er der et behov for at have mulighed for at få en samlet adgang til samlingerne i de tre institutioner, og at få søgeresultaterne vist på en ensartet måde. Vi skal bruge den moderne teknologis muligheder, til gavn for både brugerne og os selv som medarbejdere. Mangelen på ensartede standarder gør det imidlertid vanskeligt at foretage samkøring og samsøgning.

Det er vigtigt at kunne foretage samlede søgninger i de tre institutioner. Derfor er der i de senere 
år gennemført flere projekter med det sigte at gøre arkivernes, bibliotekernes og museernes samlinger tilgængelige via Internettet, bl.a. Danmarks Nationale Privatarkivdatabase, DANPA, Nordjyllands Kulturhistoriske Søgebase, NOKS, Historie Fyn og projekt Udvikling af Lokalhistoriske Netværk m.m. Til såvel DANPA som NOKS er der trukket data fra ARKIBAS.

Målet med projekterne har været at afprøve samarbejdet, og at få værdifulde erfaringer med henblik på at skabe brugbare løsninger.

\section{DANPA (Danmarks Nationale Privatarkivdata- base) (1)}

Et af de første samarbejdsprojekter, som dog kun involverede arkiver og biblioteker var DANPA, Danmarks Nationale Privatarkiv Database, som blev lanceret i 1998.

Målet var her at undersøge mulighederne for at gøre edb-registreringerne fra lokalarkiver, Statens Arkiver, specialarkiver og biblioteker tilgængelige for brugerne over Internettet. Databasen kom til at indeholde registreringer vedrørende 120.000 private arkiver. Registreringerne kom fra 190 arkivinstitutioner, bl.a. Rigsarkivet, landsarkiverne, Erhvervsarkivet, specialsamlinger som f.eks. Det Danske Udvandrerarkiv, Arbejderbevægel- sens Bibliotek og Arkiv, Dansk Folkemindesamling m.v. og 160 af de ca. 450 lokale arkiver.

DANPA, www.danpa.dk, blev fra starten en stor succes med uventet mange brugere hver dag. Projektet viste hermed, at der var et meget stort behov for at få gjort den arkivalske kulturarv let tilgængelig via en samlet præsentation og søgebase på Internettet. Der er ingen tvivl om, at DANPA har betydet, at mange brugere er blevet opmærksomme på de mange lokalarkiver og deres meget værdifulde materiale, som med DANPA nu virkelig er blevet tilgængelig for interesserede uanset hvor i verden, de opholder sig.

Lokalarkiver har i en årrække arbejdet på tværs af de egentlige institutionsgrænser mellem arkiver, biblioteker og museer (ABM). Mange lokalarkiver har fungeret som afdelinger af biblioteker eller museer, det er der ikke noget nyt i. Men den nye tendens er, at der er blevet en stadig større interesse for at undersøge mulighederne for et nærmere samarbejde mellem alle tre institutioner.

\section{NOKS (Nordjyllands Kulturhistoriske Søgebase) (2)}

NOKS, som blev lanceret i februar 2002, er et forsøg på at samk $\varnothing$ re registreringerne med billeder, lyd- og filmoptagelser m.v. fra hele ABM-områ-

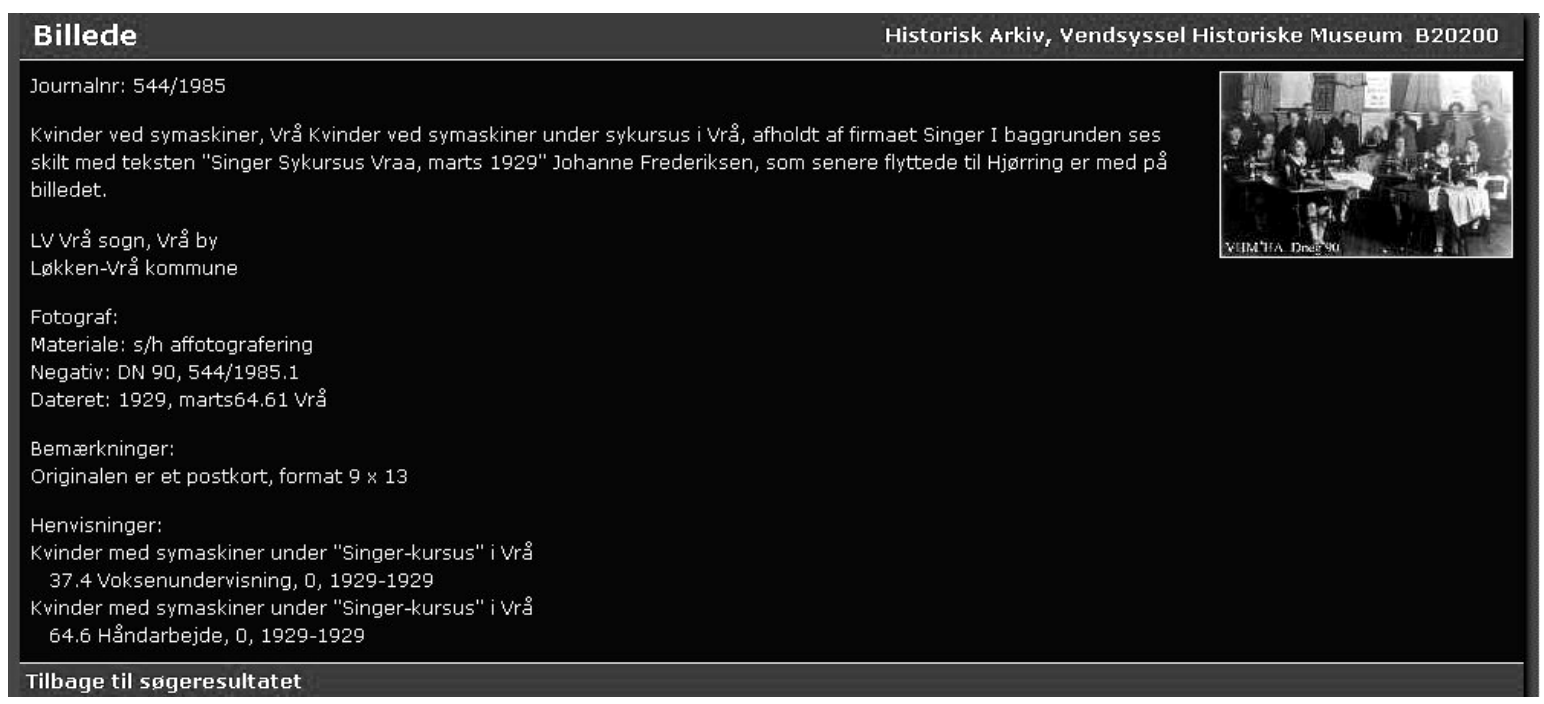

Kvinder fra Vraa på symaskinekursus i 1929. Eksempel på registrering og prasentation af arkivmateriale i Nordjyllands kulturhistoriske søgebase, NOKS. 
det, nemlig arkiver, biblioteker og museer. Indenfor det nordjyske område $\emptyset$ nskede man at sam$\mathrm{k} \varnothing \mathrm{re}$ registreringer fra lokalarkiver, kulturhistoriske museer, kunstmuseer og biblioteker, selv om de repræsenterede meget forskellig registreringspraksis. Deltagerne i projektet var Bangsbo $\mathrm{Mu}-$ seum og Arkiv, Vendsyssel historiske Museum og Historisk Arkiv, Aalborg historiske Museum, Aalborg Stadsarkiv, Vendsyssel Kunstmuseum i Hjørring, Nordjyllands Kunstmuseum i Aalborg og Det nordjyske Landsbibliotek.

Databasen kom til at indeholde 115.000 registreringer, de 8.000 med billeder, samt eksempler på lyd og film. I løbet af de første år er der blevet foretaget 60.000 søgninger i databasen. $70 \%$ af søgningerne skete i arkivernes samlinger, $15 \%$ i bibliotekernes og $15 \%$ i museernes.

Til NOKS har man trukket data ud fra hver institution og fysisk flyttet dem til en server. Før de kunne samles på serveren, måtte de konverteres til samme format, fra arkivernes ARKIBAS, fra bibliotekernes MARC-format og fra museernes DMI-format. Derefter blev de ordnet, så der var en samlet indgang til alle registreringerne.

De oprindelige søgesystemer fra de tre institutionstyper var vanskelige at samle i et fælles format. I stedet besluttedes det at lave et emne- og ordningssystem med emneord fra alle registreringerne, der giver mulighed for at gennemføre strukturerede $s \emptyset$ gninger og friteksts $\emptyset$ gning.
Databasen er naturligvis skabt for at tilgængeliggøre samlingerne for brugerne, men den er også et fors $\varnothing \mathrm{g}$ på at skabe standarder i registreringen i de kulturelle institutioner.

Fremtidsvisionen for NOKS er, at alle kulturinstitutionerne i Nordjylland med elektroniske registreringer vil have deres samlinger synliggjort $i$ NOKS.

I øjeblikket er der samarbejde med Vejle Amt, som $\emptyset$ nsker at lave en lignende database. De vil have muligheden for at skaffe sig en tom NOKS database, og dermed vil de relativt nemt kunne skabe en lignende database, idet forarbejdet og overvejelserne jo er gjort i forvejen.

\section{Historie Fyn (Fyns Lokalhistoriske Portal, Portal til dansk kulturarv) (3)}

Ved hjælp af Internettet $\emptyset$ nsker de fynske arkiver, biblioteker og museer at samle deres formidling ét fælles sted. Her skal brugerne kunne gå på opdagelse i lokalhistorien, uanset om de leder efter arkivalier, museumsgenstande, fotografier eller litteratur. Det kan ske hjemme foran skærmen.

Projektdeltagerne var Odense Stadsarkiv, Ringe lokalhistoriske Arkiv, Dalum Hjallese lokalhistoriske Arkiv, Lokalhistorisk Bibliotek i Odense, Statsbiblioteket i Århus, Middelfart Museum og Fåborg kommunes Museer. Historie Fyn blev lanceret for offentligheden i marts 2001.

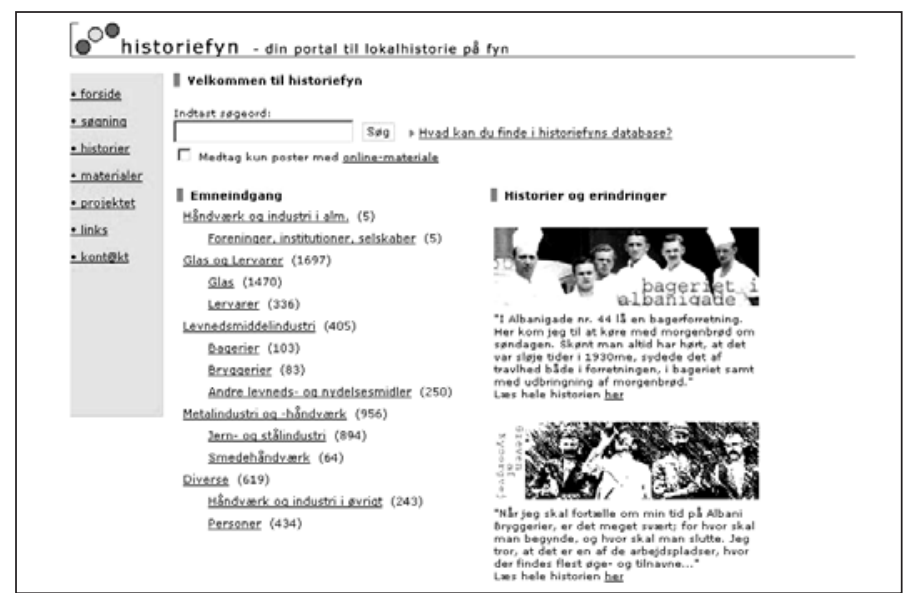

Forsiden til den lokalhistoriske portal historiefyn inviterer den historieinteresserede til at søge inden for isar fynsk håndvaerk og industri. 
Emnemæssigt har man fokuseret på emnet håndværk, som senere blev snævret ind til at omfatte emnerne: Brød, $\varnothing \mathrm{l}$, glas og jern. Databasen indeholder 4-5.000 poster, og i projektet har man valgt at berige de enkelte registreringsposter, der præsenteres på en webbaseret brugergrænseflade. Desuden udvikledes en emneklassifikation, der kunne rumme institutionernes forskellige klassifikationssystemer og udviklingen af den underliggende databasestruktur. Antallet af brugere er ikke oplyst (4).

Den oprindelige strategi med hensyn til at udtrække data var at anvende de eksisterende udtræks- og konverteringsprogrammer, der findes til ARKIBAS og DMI. Projektet fandt det dog mere hensigtsmæssigt selv at udvikle de rutiner, der skulle til. Arkiverne og museerne leverede udskrifter til filer af de relevante data, hvorfra data blev overført til databasen. Biblioteksdata blev trukket direkte ud af Odense Biblioteks onlinekatalog via de pågældende posters URL og herfra overført til databasen.

\section{Udvikling af Lokalhistoriske Netværk (5)}

Projektet er i opstartsfasen her fra 2003, og det eneste, som ikke er afsluttet.

Formålet med Udvikling af Lokalhistoriske Netværk er at styrke ABM-institutionernes formidling af lokalhistorie på nettet gennem koordinering, netværksdannelse, erfaringsopsamling og kompetenceudvikling for ABM-projekter og ABM-institutioner på området. Desuden ønsker projektet gennem eksemplets magt at skabe interesse for og incitament til at prioritere den lokalhistoriske formidling og at give brugerne lettere adgang til den viden, ABM-institutionerne har indsamlet om den lokale historie. Som fors $\emptyset$ gsområde har man valgt Viborg og man vil her skabe en webportal, der formidler Viborgs lokalhistorie på en levende måde og derved bliver en indgang til Viborg og til den historiske viden om Viborg, de medvirkende ABM-institutioner ligger inde med.

Foreløbig er deltagerne i projektet Viborg Centralbibliotek, Viborg Stiftsmuseum og Viborg Lokalhistoriske Arkiv, men man er meget åben for flere deltagere.
En væsentlig del af hjemmesiden skal bestå af historier, der er skrevet specielt til portalen, samt leksikonartikler om Viborg. Herudover lægges også indskannede fotos og artikler, arkivalier m.v. på hjemmesiden.

Det fors $\emptyset$ ges at få en dialog med brugerne i form af muligheden for at knytte brugerkommentarer til materiale i databasen. Som et af de vigtige formål søger man også at samle erfaringer op fra projekter, der er eller har været i gang og fra institutioner med vellykkede eksempler på god formidling.

Af ovenstående ses, at der i disse år tages mange initiativer med henblik på at forbedre formidlingen af den lokale kulturarv. Selvom projekterne i udgangspunktet er meget forskellige har de alle $\emptyset$ nsket at respektere den forskellige faglighed blandt de deltagende institutioner. De tre projekter har haft forskellige forudsætninger og vægtninger. Dette er også en vigtig forudsætning for succes.

I Historie Fyn har man lagt vægt på formidlingsaspektet og har valgt at berige de enkelte poster, desuden har man også valgt at fokusere på et snævert delemne og prøve at beskrive det så bredt som muligt.

I NOKS har man valgt at stille så store dele af samlingerne til rådighed for brugerne som muligt ved at tilgængeligg øre alle digitaliserede registreringer. Derfor har man lagt stor vægt på genbrug af registreringerne. Det har været vigtig for NOKS-projektet at give brugerne mulighed for at søge $i$ alt det registrerede materiale.

I Viborg-projektet har man valgt hovedsageligt at fokusere på udviklingsværktøjerne, historierne og artiklerne om Viborg, og altså valgt formidlingsaspektet. Derudover er deres erfaringsopsamling og unders $\varnothing$ gelse af igangværende aktiviteter af stor værdi for andre i ABM-institutionerne, så man får muligheder for inspiration og opdager nye idéer.

\section{Fremtidigt ABM-samarbejde}

Der er ingen tvivl om, at vi i den nærmeste fremtid kommer til at høre meget mere til begrebet 
ABM-samarbejdet. Ovenstående eksempler på samarbejde mellem ABM-institutionerne omkring formidlingen af samlinger og viden til de historisk interesserede viser, at man af den vej kan $\varnothing$ ge det kulturelle tilbud til brugerne.

Erfaringerne fra projekterne viser, at der er mange retninger i ABM-formidlingen af den lokale kulturarv.

NOKS og DANPA er gode eksempler på, at viden og samlinger kan stilles til rådighed for brugerne uanset om de sidder på en forskningsinstitution, $\mathrm{i}$ hjemmet med slægtsforskning, i eller uden for normal arbejdstid. Den type ABM-samarbejde gør det nu uden betydning, hvor i verden, den $\varnothing$ nskede information findes. Jo mere standardiseret grundregistreringerne og søgesystemerne er, jo lettere er det at opbygge databaser til fælles $\mathbf{\varnothing g}$ ning, ligesom standardisering i høj grad sikrer gennemskuelige og kvalitative søgeresultater.

De to $\varnothing$ vrige projekter har den direkte formidling af historien som hovedtema. Her satses ikke på at gøre alle deltagernes komplette samlinger tilgængelige, men derimod gennem formidlingen af spændende eksempler at give brugerne inspiration og lyst til at dykke ned i de dele af den store historiske vidensbase, som findes i ABM-institutionerne uden at være direkte tilgængelig på webportalerne. Også her er der mange muligheder, og der er ingen tvivl om, at man via den form for lokal kulturformidling vil nå et bredere publikum, end man når i NOKS og DANPA, da resultaterne er umiddelbart brugbare, ligesom billederne i de tværgående specialbaser som f.eks. Danske Billeder.

Det bliver spændende at deltage i og følge udviklingen på ABM-området i de kommende år. Der vil ske nybrud mange steder, som vil virke befordrende på arbejdet med at skabe lokale, nationale og internationale standarder. Det er vigtigt at kræve minimumstandarder for registreringerne. Derfor er det også glædeligt, at der er nedsat et udvalg med repræsentanter fra Kulturarvsstyrelsen, Biblioteksstyrelsen og arkiverne. Det er et første skridt mod nye og bedre tilstande i formidlingen af den lokale kulturarv.
I forhold til det fremtidige ABM-samarbejde er det vigtigt at have respekten for forskellighederne og hinandens fagligheder, og i den forbindelse har specielt arkiverne et problem. Mange arkiver er, som det også er beskrevet tidligere, meget små institutioner uden offentlige tilskud, med frivillig og ulønnet arbejdskraft.

Derfor er det i de kommende år vigtigt for arkiverne at arbejde for at nå op på museernes faglige niveau, det er vigtigt, at arkiverne udvikler sig til anerkendte kulturinstitutioner.

Et udbygget ABM-samarbejde bør styrke alle parter i samarbejdet og i det kulturelle landskab.

\section{Noter}

1. www.danpa.dk

2. www.noks.dk

3. www.historiefyn.dk

4. http://www.historiefyn.dk/rapporter/ Rapport_historiefyn.rtf

5. http://www.lokalhistorisknet.dk/ projekt/default.asp

\section{Litteratur}

DanPa - Danmarks nationale privatarkivdatabase (1999). Af Asbjørn Hellum, Mogens Thøgersen og Jens Topholm. I: Arkiv, tidsskrift for arkivforvaltning og arkivteknik, nr. 4, s. 7-12.

Folkets arkiver (1989). Sammenslutningen af lokalhistoriske Arkiver 1949-1989. Red. Poul Sverrild. Esbjerg, Sammenslutningen af Lokalhistoriske arkiver, $79 \mathrm{~s}$.

Hellum, Asbjørn (1996). ARKIBAS - vejen til lokalhistorien. I: Lokalhistorie uden graenser. Festskrift til Anders Friedrichsen. Farum, Farums Arkiver og Museer, s. 59-73.

Porskær Poulsen, Poul (1997). Vi passer på historien. En undersøgelse af lokalarkiverne. Vejle, Sammenslutningen af Lokalarkiver, $118 \mathrm{~s}$. 